\title{
SAND AND MUD COMMUNITIES IN THE DOVEY ESTUARY
}

\author{
By F. Louise Beanland, M.Sc. \\ Lecturer in Biology, Municipal College, Portsmouth
}

(Text-figs. I-3)

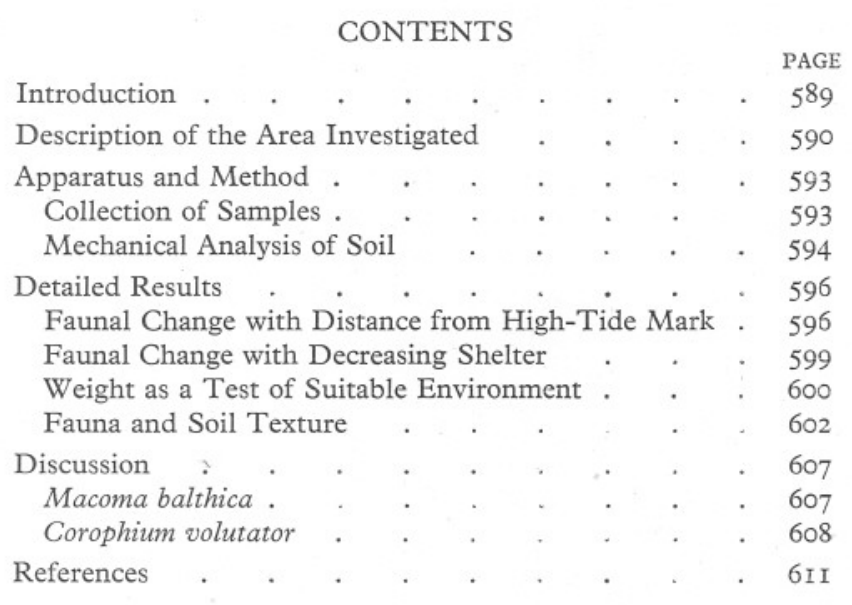

\section{INTRODUCTION}

This paper presents results of an ecological study towards high-tide level near the mouth of the Dovey estuary, carried out in 1925-6. The area was treated as an extension of the sea floor, the only comparable work at that time being submarine. Petersen (I9I8) showed that on the bed of shallow seas the fauna could be grouped into "animal communities", whose constitution was determined by depth, distance from shore, shelter and salinity. Analysed with regard to distance from high-water mark, and degree of shelter, the fauna of this part of the estuary shows Petersen's Macoma community over most of the area, with a Corophium community at high tide in the more sheltered part. Davis (1925), in the North Sea, substituted "soil associations" as an alternative ecological unit, a certain grade of soil carrying its typical fauna wherever it might be found. The two groupings already found in the Dovey estuary clearly emerged as soil associations, after adoption of a reliable method for analysis of fine-grade soils. Up to the present, oceanographers have used sieves or elutriation for soil analysis. These methods are unsatisfactory for examinations of estuarine soils, with their large proportion of fine material. 
Not only do they fail to subdivide the finer grades of soil, but they are inaccurate in measuring the lower range they do register. Variety in methods of soil analysis, and lack of uniformity in fixing soil grades, make present data on estuarine soils of little value for comparative purposes. Investigation of the current agricultural method of soil analysis, devised by Robinson, proved it eminently suitable, in that it offers infinite possibilities for accurate subdivision of fine grade soils, and a simple and practically foolproof technique. The minimum particle diameter measured was $0.002 \mathrm{~mm}$. It is suggested the method might profitably be employed for estuarine work in general.

Some suggestions are put forward regarding possible factors affecting the distribution of Corophium volutator and of Macoma balthica.

The fauna have been named in accordance with the Plymouth Fauna List (Marine Biological Association, I93I) with the exception of Corophium arenarium n.sp. Crawford, 1937, fourn. Mar. Biol. Assoc., Vol. xxi, p. 598.

I wish to express my gratitude to Professor R. D. Laurie, M.A. for helpful advice and criticism during the course of this investigation; and to Dr E. E. Watkin for his kindness in helping me to bring the work up to date for publication. I should also like to thank Miss Blodwen Williams for her unfailingly cheerful help in obtaining the samples.

\section{DesCription OF THE AREA INVESTIGATEd}

Fig. I shows a map of the mouth of the sandy Dovey estuary, narrowed to a "bottle-neck" by sand dunes and Aberdovey Bar. Comparative shelter from west winds and tide is afforded by the dunes, and the tide does not rise in the estuary till it has been running at least an hour outside the bar. The area investigated, lying within the effective shelter of the dunes, is indicated by diagonal lines on the map. Its landward limit is a dyke, protecting the reclaimed land behind. On its western side it ends on the bank of the River Leri, flowing seawards from an artificial channel through Borth Bog.

Fig. 2 shows greater detail of this area and the locations of samples. It was made from field data obtained by paced measurements and a pocket compass. Over soft or difficult ground an overestimate of distance may be expected, and the experimental error will be variable. With one exception (sample 26) investigation was limited westward by the top of the Leri bank, but this line must not be read as low-water mark. Two major gullies traverse the area, and at low tide the streamlet is some distance away from the discernible edge of the gully. Samples were in some cases taken within this edge, as shown on the map.

The slope of the ground is imperceptible except at the gullies, becoming greater at the cockle bed at the northern limit of the area mapped in Fig. 2. Except over this region the water movement is normally gentle, lines of footmarks remaining obvious for over a week. In November 1925 the northern 
Macoma-Bathyporeia patch was on a bank of coarser, very loose sand, above the level of samples to the east. By the following February this bank had disappeared, indicating considerable water movement.

The lower-lying gullies make comparative distances from high-water mark not directly comparable with comparative periods of emersion. High water of spring tides is well up the dyke, but high water of neap tides merely swells



Fig. I. Map of the mouth of the Dovey estuary. The area investigated ( $c a . \frac{3}{4} \times \frac{1}{2}$ miles) is indicated by diagonal lines.

gully I, leaving dry soil on each side. In spite of this, however, the exposed soil does not, except in the south-west corner, become very dry in the interval. Its continual wetness is probably due to land drainage along the slope of the clay beneath, finally collecting up into the gullies, so that, unlike high-water levels in many estuaries, this part may be expected to show considerable salinity variation with the state of the tide. The sand to the north, however, is dry compared with that nearer high-water mark to the east. Other points of possible importance are the introduction of bog water by the Leri, and of sewage from Aberdovey, which, according to Durlacher (I9I4) ponds within the estuary as a result of the presence of the sand dunes. 


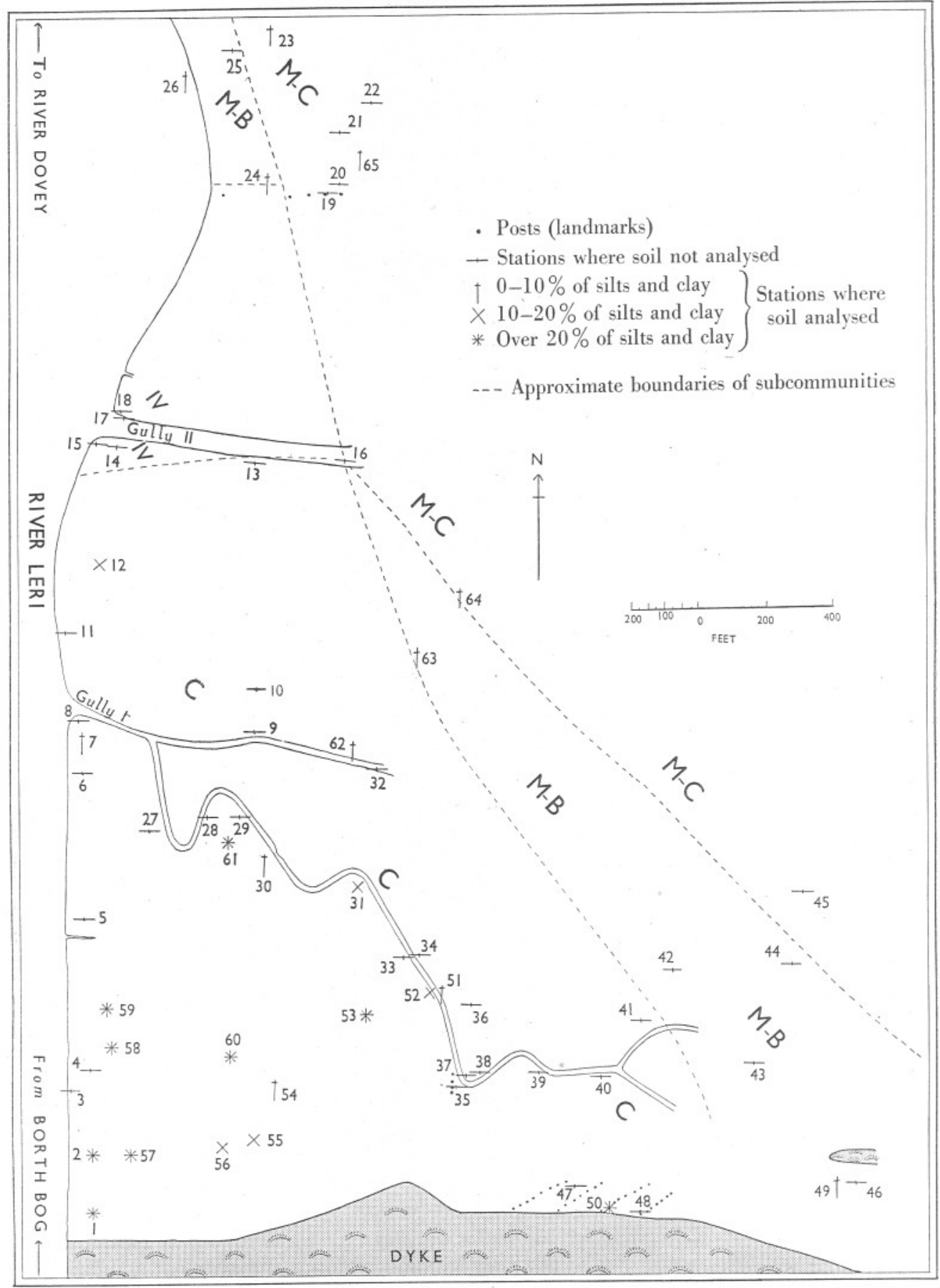

Fig. 2. Map of the eastern bank of the Leri in I925. The Leri and the gullies are outlined as the top of the bank or, where this gives place to a gradual slope, to a delimiting line of soil along it. $C=$ Corophium community; $M-B=$ Macoma-Bathyporeia subcommunity; $M-C=$ Macoma-Cardium subcommunity. Location of sample lies on intersection of lines. 
The samples cover three easily distinguished types of soil. The south-west corner forms a patch of firm, sticky, grey mud with a bad skid surface. In an arc around this is softer, darker mud, finally giving way to the sand covering most of the estuary.

Within this general division into harder and softer mud, and sand, there is much local variation, both in nature of soil and degree of wetness, and the fauna appear to show a variation with both these factors.

Over most of the area the ground is bare. Scattered plants of Salicornea Europea were present in the south-west corner of sticky mud, but Enteromorpha formed a more obvious feature, and reappeared patchily on the northern cockle bed. Fucus serratus also occurred at the base of the posts in this region.

\section{Apparatus AND Method}

\section{Collection of Samples}

For faunal counts a layer of soil I ft. sq. $\times I$ in. deep was cut out with a Beach Sampler, described below; and washed through a sieve of I mm. mesh, separating macrofauna and large fragments from microfauna and soil particles, which were neglected. Previous work in the area seemed to indicate that the surface inch contained a representative infauna. Samples for soil analysis were removed from the surface inch just outside the square, and bear the same reference number as the corresponding faunal sample.

To cut out the layer, two superimposed metal rings, each I in. deep and fitting over each other by pin and socket, were rammed into the soil, cutting edge downwards, until flush with the surface. A square metal frame of side I ft. and with I in. height marked was forced inside this ring to the depth of $I$ in. The top ring was next removed and, after sufficient space had been gained by shovelling away sand from outside the square; a metal plate, also with a cutting edge, was forced horizontally between the square and the top of the second ring, an accurate square foot sample of the surface soil being thus obtained.

Over most of the area this method gave perfectly satisfactory sampling. Samples 20-23 inclusive, however, give a lower estimate of cockles than is representative for the area. Here the cockles were numerous enough to give the impression of ground closely and finely cobbled, with a thin overlay of sand. It was impossible to make any impression on this with a spade in most parts, and samples had therefore to be taken from patches relatively free of cockles. Even here, however, there was a maximum sampling of I49 per sq. ft. $\left(=c a .1580\right.$ per m. $\left.{ }^{2}\right)$ as compared with 100-200 per m. ${ }^{2}$ given as typical of a good ground by Spooner \& Moore (1940, p. 317). 


\section{Mechanical Analysis of Soil}

Four possible means of measuring soil particle size are: (I) by graduated sieves (Allen, I899), (2) by elutriation, (3) by fractional sedimentation; (4) by rate of subsidence through a standing column of dispersion.

(i) Analysis by sieving is not suitable for fine soils. A mesh of diameter less than $0.2 \mathrm{~mm}$. soon becomes inaccurate through wear; while if the sample is sieved dry, clay tends to fly off, and if wet, tends to "puddle" and clog the mesh.

(ii) Analysis by elutriation. Borley (1923) devised a three-chambered elutriator, once recognized as the standard apparatus for marine soils, which separated two grades of size- 0.5 to $0.1 \mathrm{~mm}$. diameter and 0.1 to $0.05 \mathrm{~mm}$. diameter, finer soil being swept out and estimated by loss. Fraser (1932) used a four-chambered elutriator measuring a minimum particle diameter of $0.02 \mathrm{~mm}$. Pirrie et al. (1932) varied the rate of current through a single tube elutriator, sweeping out successively coarser particles with increasing current, and recognizing a minimum diameter of $\mathrm{O} . \mathrm{I} \mathrm{mm}$. only. These methods, again, do not allow for subdivision of the finer fraction of a soil, possibly of vast importance to an estuarine fauna. Borley's apparatus, at least, was also found to give inaccurate results when the sample contained a large percentage of fine material. An initial rate of flow appropriate for supporting the various grades in their respective chambers was found to increase to the point of serious error, with decreasing resistance of the sample as a growing fraction was removed by the current. An actual example may make this clear:

(I) Initial rate of flow $=I 87$ c.c. per $100 \mathrm{sec}$.

(2) Immediately after introduction of sample: rate = I IO c.c. per IOO sec.

(3) Just before removal of sample: rate $=$ I50 c.c. per $100 \mathrm{sec}$.

(4) After removal of sample: rate $=190$ c.c. per $100 \mathrm{sec}$.

Thus it would be necessary, for each sample, to find by experiment the initial flow giving I IO c.c. per IOO sec. on introduction of sample; and then to adjust the flow during sampling to maintain this rate. Accuracy of analysis would be uncertain under these conditions.

(iii) Fractional sedimentation. Rees (I940) has tried this method, and, like myself, found it unsatisfactory. Soil grades are not cleanly separated.

(iv) Rate of subsidence through a standing column. The only method found suitable and reliable for analysis of fine-grade soils was that of Robinson for agricultural soils (I922). The soil analyses given in this paper were obtained by the use of Robinson's 1922 method in which the following soil grades were recognized:

(I) Separated by sieving through sieves of standard mesh:

Fine gravel 2.5 to $1.5 \mathrm{~mm}$. and any coarser grades.

(2) Separated by sieving after treatment by hydrochloric acid:

Very coarse sand $\mathrm{I} \cdot 5$ to $\mathrm{I} \cdot 0 \mathrm{~mm}$.

Coarse sand $\quad \mathrm{I} \cdot 0$ to $0.5 \mathrm{~mm}$.

Medium sand 0.5 to $0.2 \mathrm{~mm}$. 
(3) Separated by subsidence in an ammoniacal dispersion after thorough shaking:

$\begin{array}{ll}\text { Fine sand } & 0.2 \text { to } 0.04 \mathrm{~mm} . \\ \text { Silt } & 0.04 \text { to } 0.01 \mathrm{~mm} . \\ \text { Fine silt } & 0.01 \text { to } 0.002 \mathrm{~mm} . \\ \text { Clay } & \text { Less than } 0.002 \mathrm{~mm} .\end{array}$

Hygroscopic moisture was calculated in a sample of the air-dried soil and "organic matter" by loss on ignition in a muffle furnace.

Since 1922 the details of Robinson's method have been somewhat revised by the International Society of Soil Science and the Chemistry Committee of the Agricultural Educational Association. Full details of the method, as at present used for the analysis of agricultural soils, are given in an appendix to Vol. v (1928) of Agricultural Progress, and a further discussion of the method in its application to the many varying types of soil throughout the world is given in "The dispersion of soils in mechanical analysis", Technical Communication No. 26 of the Imperial Bureau of Soil Science, London, I933.

The modifications introduced have resulted in the recognition of somewhat different soil grades which may be summarized as follows:

(I) Separated by sieving through a standard round-hole $2 \mathrm{~mm}$. mesh sieve: Stones and fine gravel, particles greater than $2 \mathrm{~mm}$.

(2) Separated by sieving through a standard square aperture $0.2 \mathrm{~mm}$. mesh sieve after treatment with hydrogen peroxide to remove the organic matter and hydrochloric acid to remove the carbonates:

Coarse sand, 2.0 to $0.2 \mathrm{~mm}$.

(3) Separated by sedimentation and by subsidence in an ammoniacal dispersion after thorough shaking:

Fine sand by sedimentation, 0.2 to $0.02 \mathrm{~mm}$.

Silt by subsidence (pipette sampling), 0.02 to $0.002 \mathrm{~mm}$.

Clay by subsidence (pipette sampling), less than $0.002 \mathrm{~mm}$.

In addition, $(a)$ the moisture content of the air-dried soil, $(b)$ the carbonates expressed as calcium carbonate, $(c)$ the loss by solution in the hydrogen peroxide, hydrochloric acid treatment (mainly the sesquioxides of aluminium and iron and the silica), $(d)$ and the loss on ignition, which includes the organic matter and the combined water in the soil colloids, are estimated. These, together with the particles, are expressed as percentages of the air-dry soil.

I am of the opinion that the adoption of Robinson's method to marine and estuarine soils, with possibly slight modifications due to the "salt content" of such soils, and the lack of importance of the hygroscopic moisture of truly submarine soils, will prove of value to the marine biologist.

In considering the refinements of the agricultural method for application to marine soils, however, it is well to bear in mind the different object of the agriculturist. $\mathrm{He}$ is concerned with improving his soil to support a more profitable flora, and seeks to know its ultimate constitution. Improvement of 
the soil-except by cutting Zostera, for example-is outside the scope of the marine biologist. He is only concerned with untouched soil in its effect on a fauna. For example, we may imagine an estuarine soil of apparent silt. The agriculturist, after $24 \mathrm{hr}$. shaking and chemical treatment, might record much of this as finer grades. If it never appeared in this guise in the area concerned, the marine biologist might be wiser to neglect this drastic treatment and record it as silt, for correlation with its effective result in supporting a fauna adapted to conditions associated with soil particles of this average size. Hence additions to the agricultural methods since I 922 should be adopted only after investigation.

\section{Detailed Results}

The location of samples ( $\mathrm{I} \mathrm{ft}$. sq. $\times \mathrm{I}$ in. deep) is shown in Fig. 2 , and the results are given in three series, viz.:

(I) Table I and samples I-26, Fig. 2, show faunal change with distance from high-tide mark.

(2) Table II and samples $27-48$, Fig. 2 , show faunal change with decreasing shelter.

(3) Table VI and samples 49-65 (with some of the previous ones) show faunal change with increasing fineness of soil.

In addition, weights of certain species are shown in Table III; Table IV gives detailed results of soil analysis; Table VII and Chart I demonstrate more clearly the presence of two soil associations.

\section{Faunal Change with Distance from High-Tide Mark}

Twenty-six samples were taken from high tide three-quarters of a mile towards low tide, not in a straight line, roughly along the banks of the Leri. Other variable factors in this series will be increased immersion, not progressive for every station, and some decrease in shelter.

The infauna falls into two well-defined groups, samples I-I3 lying across a Corophium ground, of which the typical animals are grouped together in section I, Table I; and 19-23 entering a Macoma belt, with Cardium edule as the subdominant form, together with Corophium arenarium, and whose typical animals are grouped in section II, Table I. This section is considered to be an intertidal phase of Petersen's "Macoma community", including as it does Macoma balthica, Cardium edule, Arenicola marina (small forms only were obtained in the surface inch examined, but surface casts were numerous) and, as epifauna on the posts, three other species which occur "practically speaking only within the area of the Macoma community" (Petersen, I9I8), viz. Mytilus edulis and dense clusters of Littorina littorea at the base, and Balanus balanoides higher up. During the investigation no distinction was made between the two species of Corophium, as C. arenarium had not then been described. The two species, typical of mud and of sand respectively, do not commonly occur together in one sample, and on this basis, on the authority 
Table I. Faunal Change with Distance from High-Tide Mark

$\begin{array}{llllllllllllllllllllllllllllllllll}\text { Sample no. } & \ldots & \text { I } & 2 & 3 & 4 & 5 & 6 & 7 & 8 & 9 & \text { IO } & \text { II } & \text { I2 } & \text { I3 } & \text { I4 } & \text { I5 } & \text { I6 } & \text { I7 } & \text { I8 } & \text { I9 } & 20 & 2 \text { I } & 22 & 23 & 24 & 25 & 26\end{array}$ Section I

Corophium volutator (Pallas)

Nereis diversicolor Müller

Oligochaeta (pitted)

Oligochaeta (smooth)

Nematoda

Leptidae larva (Diptera)

Heterocerus obsoletus (Coleo-

ptera)

Hydrobia ulvae Pennant

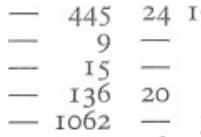

- $1062-\overline{8} \quad 35$

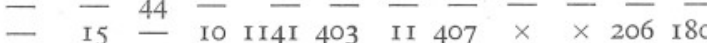

Section II

Macoma balthica (Linnaeus)

Cardium edule Linnaeus

Arenicola marina Linnaeus

Corophium arenarium Crawford -

Pygospio elegans Claparède

Eulalia sp.

Scoloplos armiger (Müller)

Retusa alba (Kenmacher)

Scrobicularia plana (da Costa)

Tellina tenuis da Costa

Praunus flexuosus (Müller)

Crangon vulgaris Linnaeus

Section III

Bathyporeia pilosa Lindström Ophelia limacina (Rathke)

Nerine sp.

Eurydice pulchra Leach

\section{Section IV}

Glycera convoluta Keferstein

Spio filicornis Fabricius

Nephthys sp.

Sphaeroma serratum (Fabricius)
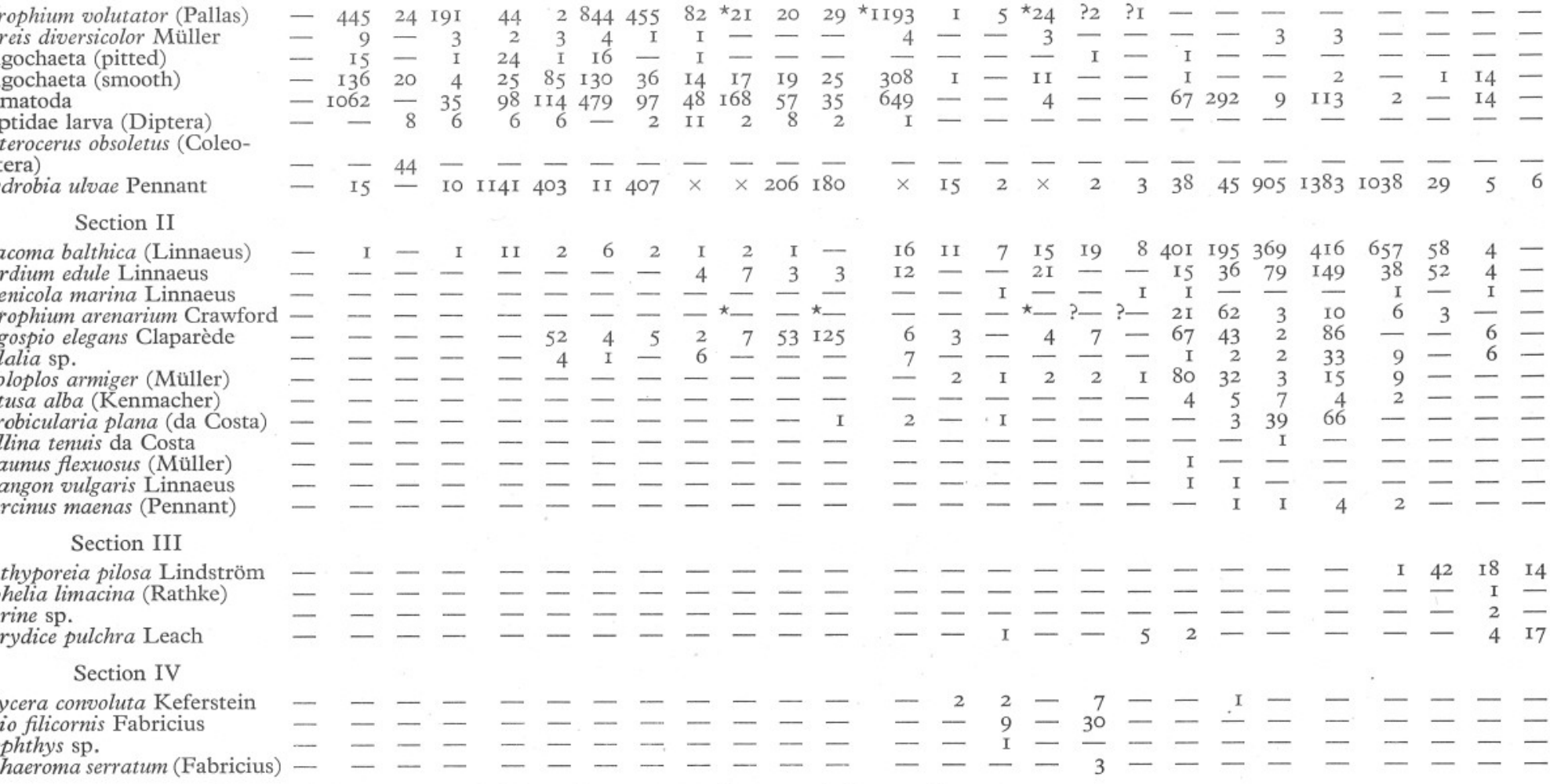

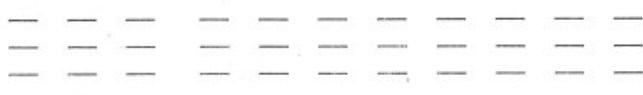

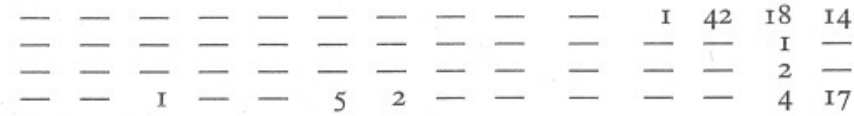

* Probably a mixture of $C$. volutator and $C$. arenarium.

? Possibly $C$. arenarium instead, or in part (see Table III and text). 


\section{Table II. Faunal Change with Decreasing Shelter}

Period of sampling-November and December

Corophium volutator

Nereis diversicolor

Oligochaeta (pitted)

Oligochaeta (smooth)

Nematoda

Leptidae larva

Paragnathia formica $\hat{\theta}$

Paragnathia formica 오

Paragnathia formica larval

Hydrobia ulvae

Macoma balthica ( $a$ )

Macoma balthica $(b)$

Macoma balthica (c)

Cardium edule (I)

Cardium edule (2)

Cardium edule (3)

Cardium edule (4)

Corophium arenarium

Pygospio elegans

Pygospio eleg

Retusa alba

Carcinus maenas

Bathyporeia pilosa

$\begin{array}{rrrr}27 & 28 & 29 & 30 \\ 5 & 81 & \text { I42 } & \text { I4 } \\ 2 & - & - & 3 \\ 5 & - & - & 7 \\ \text { I3 } & 24 & 8 & \text { I5 } \\ 44 & 91 & \text { I2I } & 238 \\ \text { I9 } & \text { I3 } & \text { I7 } & \text { I } \\ - & - & \text { I } & -\end{array}$

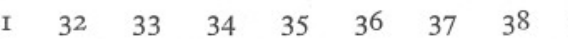

- $-37-2-298-2-1-1-$

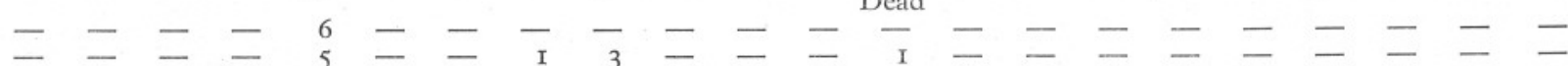

$26292 \times \times \times \times 4 \mathrm{I} 733 \mathrm{II} 7 \times 3360 \mathrm{IO} 2 \mathrm{I} \times \times \mathrm{I} 734 \times \mathrm{IO} 43 \times \times \times 4 \mathrm{I} 69 \times 5$

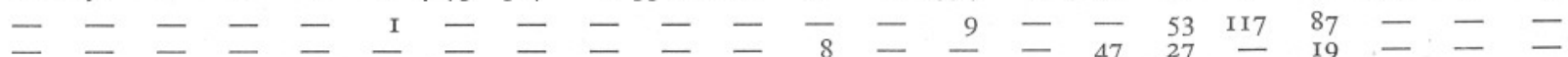

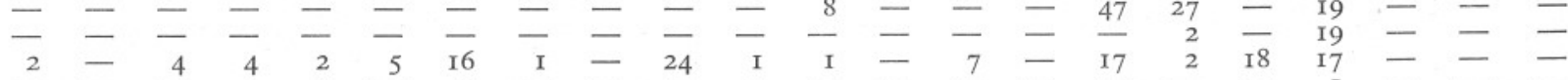

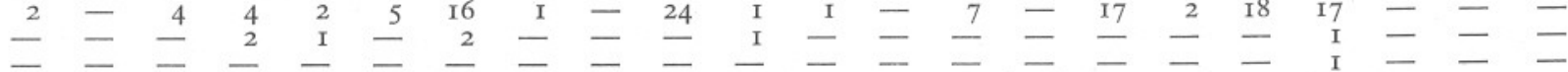

- - - - - - - 2 - - - - - - - - -

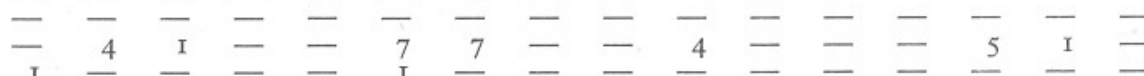

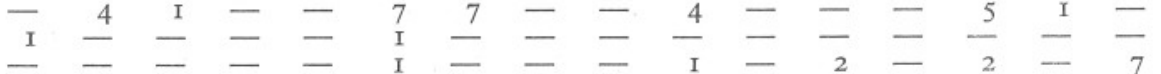

- - - - I $-\frac{1}{2}-1-$

$\begin{array}{llllll}7 & \mathrm{I} & 2 & \overline{40} & \mathbf{4 0 I} & \overline{66}\end{array}$

$5-1-1-$

$\begin{array}{llll}5 & 3 & \text { I } & -\end{array}$ 
of Dr Watkin, a separation of the two species has here been made. In August, I938, the neighbourhood of sample I6 was found to contain a mixed population of the two, and as $C$. volutator is found to make a seasonal migration away from the gullies, it cannot now be determined which species constituted the Corophium noted in samples 9, IO, I3 and 62. Movement over the area is further indicated by the fact that in September 1925 Corophium was found swimming in the pools at the base of the posts, shown on the cockle bed, although it was absent from the neighbouring soil.

Two other sections are tabulated, section III, samples 24,25 and 26, in more barren sand between the Macoma-Cardium ground and the Leri, in which Bathyporeia pilosa appears in numbers, may represent a Macoma-Bathyporeia subcommunity. In the transitional area between mud and sand (samples I4, I5, I7 and I8) a few species, chiefly polychaetes, make their sole appearance, and are grouped together in section IV.

Sections I and II are rendered more sharply distinct than they appear in the table by the fact that any section II animals found in samples I-I3 are all of smaller size than in the area considered typical for them, with the possible exception of Scrobicularia. This suggests that their presence nearer high-tide mark is limited to only a short time after spat fall or metamorphosis, and that the area is intrinsically unsuitable. The only obvious trespasser from section I is the nematode, which may actually include more than one species.

Hydrobia ulvae has not been taken into consideration in this grouping of the infauna, as it is largely a surface dweller. In view of Spooner \& Moore's statement (I940, p. 327) that it is especially susceptible to disturbance of the ground by currents, it may be interesting to notice the increase in their numbers in the lee of a bank (samples $2 \mathrm{I}, 22,23$ ) compared with their relative scarcity somewhat nearer high-water mark. Samples 22 and 23 show especially high figures, and are the only two samples where the presence of Enteromorpha was noted, possibly affording additional effective substrate as suggested by Spooner \& Moore for Zostera (I940, p. 3II).

\section{Faunal Change with Decreasing Shelter}

By taking a series of samples along gulley I, working away from the sheltering dune bank, it was possible to investigate the effect of shelter, with that of distance from high-tide line (and therefore period left uncovered) practically eliminated. Twenty-two samples (27-48 on Fig. 2) were made to cover this investigation, and Table II shows that the "Corophium community" is restricted to a very small part of the high-tide area, again giving place to the "Macoma community" about sample 42. Dr Watkin informs me that Corophium volutator does not recur higher in the estuary until the next freshwater streamlet emerges on to the flood plain. In April r925 I found a few at Glandyfi, five miles up, at the head of the estuary. Again, the distribution of $C$. arenarium differs from that of $C$. volutator, following more closely that of Bathyporeia pilosa, and occurring with it in the drier patches in the wet Arenicola ground covered by samples $43-46$. The order of dryness of these is 
46 (driest), 43, 44, 45 (wettest) and the numbers of the two species mentioned decrease in that order of samples. Corophium arenarium, however, has its maximum density of population on a strip parallel to the dyke, in which sample 47 is included, and which does not appear so favourable to Bathyporeia.

In this series Hydrobia ulvae was not counted in each sample, but only in the samples containing the maximum and minimum number for each journey, thus saving a good deal of time. The total is recorded as $x$ in the uncounted samples. The area covered by samples $36-46$ inclusive seems to include the optimum for the species, having an average of about 1898 per sq. ft.-about 20,000 per $\mathrm{m} .{ }^{2}$, while the maximum is $4 \mathrm{I} 69$ per sq. $\mathrm{ft}$.-about 44,200 per m. ${ }^{2}$ Spooner \& Moore (I940) point out that the maximum density for this species is usually high up on the beach, and give their own maximum at about 35,000 per $\mathrm{m} .{ }^{2}$

\section{Weight as a Test of Suitable Environment}

It has already been suggested, in considering Table I, that the "trespassers" from one community to another attain only a relatively small size. This suggestion was checked by recording the average "dry" live weight per species per sample for certain species, calculated from $\frac{\text { total weight }}{\text { number of individuals }}$ shown in Table III. Animals comparatively few in number, e.g. Nereis, Pygospio, were not weighed; nor were nematodes and oligochaetes, for those retained by the I mm. mesh are much of a size.

Only Corophium volutator, C. arenarium, Bathyporeia pilosa, Macoma balthica and Cardium edule were therefore weighed. Corophium and Bathyporeia were allowed to scramble, roll or wriggle across sheets of blotting paper till they left no further trail and appeared to be dry, and the molluscs were divided into groups and left to dry until surface water had evaporated. Macoma was divided up into three grades, which were determined after inspection of a large number of individuals. The three grades were:

(a) I to $3 \mathrm{~mm}$. across broadest part; colourless or very pale.

(b) 3 to $8 \mathrm{~mm}$. across broadest part; typically shiny pink or yellow.

(c) $8 \mathrm{~mm}$. to largest sizes; generally a ringed, calcareous appearance.

Support for this grading is afforded by Horsman (unpublished) who finds Macoma grows from March to July at a rate of about I mm. per month. In its first season it attains a breadth of $3 \mathrm{~mm}$.; in its second, $7 \mathrm{~mm}$.; after which the generation becomes indistinguishable.

Cardium edule was easily divided by counting the number of annual rings, this number $(\mathrm{I}-4)$ being indicated in brackets in Table II and again in Table III.

In samples 34 and 37 many Corophium volutator were dead when examined, so could not be dried by the method adopted. Hence the average weight in sample 34 was calculated from some only of the total number, while no attempt was made to weigh those in sample 37.

Table III shows the position most favourable to the species investigated. Considering first Cardium-four year groups are present together only in 
Table III. Average Weight (mg.) of Selected Species in DifFerent SAMPles

\begin{tabular}{|c|c|c|c|c|c|c|c|c|c|c|}
\hline \multirow{2}{*}{$\begin{array}{c}\text { Sample } \\
\text { no. }\end{array}$} & \multirow{2}{*}{$\begin{array}{l}\text { Corophium } \\
\text { volutator }\end{array}$} & \multirow{2}{*}{$\begin{array}{l}\text { Corophium } \\
\text { arenarium }\end{array}$} & \multirow{2}{*}{$\begin{array}{l}\text { Bathyporeia } \\
\text { pilosa }\end{array}$} & \multicolumn{3}{|c|}{ Macoma balthica } & \multicolumn{4}{|c|}{ Cardium edule } \\
\hline & & & & $a$ & $b$ & $c$ & I & 2 & 3 & $\overrightarrow{4}$ \\
\hline 29 & $\mathrm{I} \cdot 2 \mathrm{II}$ & - & - & - & - & - & 0.025 & - & - & - \\
\hline 30 & $I \cdot 42$ & - & - & - & - & - & 0.00 & I $8 \cdot 5$ & - & - \\
\hline $3 I$ & $I \cdot 46$ & - & - & - & 一 & - & I & 57 & - & - \\
\hline 32 & 0.65 & - & 0.2 & 0.00 & . - & - & $6 \cdot 48$ & - & - & - \\
\hline 33 & 5.33 & - & - & - & - & - & $2 \cdot 35$ & 19.65 & - & $2574 \cdot 5$ \\
\hline 34 & 7.02 & 一 & - & - & - & - & $35 \cdot 4$ & - & - & - \\
\hline 35 & $3 \cdot 27$ & - & - & - & - & - & - & - & - & - \\
\hline 36 & 2.04 & - & - & - & - & - & $5 \cdot 85$ & - & - & - \\
\hline 37 & $?$ & - & - & - & - & - & $33 \cdot 4$ & $4230 \cdot 2$ & - & - \\
\hline 38 & 0.2 & - & 0.3 & - & I6.68 & - & IO 4 & - & - & - \\
\hline 39 & I $\cdot 84$ & - & - & - & - & - & - & - & - & - \\
\hline 40 & $\mathrm{I} \cdot 03$ & - & - & 0.01 & - & - & $3 \cdot 71$ & - & - & - \\
\hline $4 \mathrm{I}$ & $3 \cdot 3$ & - & - & - & - & - & - & - & - & - \\
\hline 42 & - & - & - & - & 109.36 & - & $7 \cdot 62$ & - & - & - \\
\hline 43 & - & 0.09 & 0.96 & 0.38 & I. 89 & $200 \cdot 2$ & $O \cdot I$ & - & & - \\
\hline 44 & 二 & $\begin{array}{l}0.00 \\
0.2\end{array}$ & ? & - & 17.82 & $\overline{0}$ & $30 \cdot 9$ & $\overline{2 \pi}$ & $\overline{50} 6$ & - \\
\hline $\begin{array}{l}45 \\
46\end{array}$ & - & $\begin{array}{l}0.2 \\
2 \cdot 5\end{array}$ & $\begin{array}{l}0.12 \\
I \cdot 26\end{array}$ & $\underline{0.4 I}$ & $34 \cdot 89$ & $218 \cdot 89$ & 15.9 & $37 \cdot 4$ & $31 \underline{50} \cdot 6$ & $5192 \cdot 9$ \\
\hline 47 & - & $2 \cdot 61$ & 0.16 & - & - & - & - & - & - & - \\
\hline \multirow[t]{2}{*}{48} & - & 0.45 & 0.13 & - & - & - & - & - & - & - \\
\hline & orophium spp. & & & & & & & & & \\
\hline 9 & $I \cdot 22$ & - & - & 0.00 & - & - & $9 \cdot 6$ & - & - & - \\
\hline Io & $I \cdot 54$ & - & - & 0.00 & - & - & I. 49 & - & - & - \\
\hline 13 & $\mathrm{I} \cdot \mathrm{I} 8$ & - & - & $\mathrm{I} \cdot \mathrm{O} 2$ & $84 \cdot 78$ & $75 \cdot 7$ & 295.04 & - & $7043 \cdot 4$ & - \\
\hline I6 & 0.9 & - & - & 2.65 & $106 \cdot 39$ & $240 \cdot \mathrm{I}$ & 120 & $2717 \cdot 3$ & $5285 \cdot 7$ & $7955 \cdot 5$ \\
\hline 62 & 0.9 & - & - & - & - & - & 5 & - & - & - \\
\hline 63 & - & - & 0.2 & $\overline{0}$ & - & - & $29 \cdot 3$ & $\overline{-}$ & $\overline{-8}$ & $\overline{-16}$ \\
\hline 64 & - & - & 0.68 & 0.67 & I79.5 & $240 \cdot 2$ & $46 \cdot I$ & $1256 \cdot 3$ & $4078 \cdot 2$ & $3346 \cdot 5$ \\
\hline
\end{tabular}


samples I6, 64, 45; and there is a rim of heavy first year Cardium round this in samples I3, 63, 44 (37 having heavy forms too). The remaining Cardium collected lie within the Corophium zone. Samples 9, 62, 32-close to the edge of the gully-have fairly well-grown forms; and some second-year Cardium were also found in samples along gully I. The remaining Cardium samples (I0, 43-places uncovered slightly longer) contain only the first-year group and the average weight is very low. From this it appears that a line through samples I6, 64 and 45 represents the edge of the Cardium-bed proper, with a bordering zone of well-grown first-year forms. Cardium invading the Corophium zone does not live very long, doing best on the edges of the gullybed (where the tidal effect lasts longest) but growing little, or perishing, in the areas subjected to still longer drying.

The edge of the established Macoma ground coincides fairly well with that of Cardium, but also extends to samples I3 and 43. South of this the smallest group occurs alone in samples 9, 10, 32 and 40-again by the gully-but the average weight of these is considerably less than that of first-year forms in the Macoma ground proper.

The average weights of Corophium volutator show that the heaviest average (7.02 mg.) was found in sample 34, the weight getting steadily less downstream towards the Leri, decreasing less steadily in the opposite direction. Such a gradation might be due, among other things, to difference in growth rate, or in breeding rate and proportion of young. C. arenarium does not attain so large a size as $C$. volutator, the heaviest average found being only $2.6 \mathrm{I} \mathrm{mg}$. The observed fall in average weight through samples I0, I3, I6, might be due to an increased proportion of $C$. arenarium in a mixed population, but this cannot now be determined.

The figures for Bathyporeia pilosa show its association with Corophium arenarium, and like this species it seems to "prefer" drier patches. For instance, in the series $46,43,45$, passing from fairly dry to wet sand, the average weight steadily decreases, with a drop in the numbers of $C$. arenarium. Sample 47 was drier than 48 and had more numerous, heavier individuals of both species. Sample 63 was an exception in having large numbers of Bathyporeia (298) although it was very wet, but the individuals were all small.

\section{Fauna And SoIl Texture}

Table IV shows the complete analysis for twenty-three samples, included in full for reference. In calculating Representative Numbers (Borley I923, p. 30) the division of sand into medium and fine was ignored, being considered to stress unduly one of the less important ecological factors. Throughout, I00 $\times$ R.N. has been used to get a whole number. The R.N. was calculated from the following grades of size:

$\begin{array}{lll}\text { Sand } \ldots & \ldots & 0.04 \mathrm{~mm} . \text { minimum diameter. } \\ \text { Silt } \ldots & \ldots & 0.01 \mathrm{~mm} . \text { minimum diameter. } \\ \text { Fine silt } & \ldots & 0.002 \mathrm{~mm} \text {. minimum diameter. }\end{array}$


Table IV. Complete Soil Analysis for 23 Samples Shown in Fig. 2.

Proportions by weight of different grades given in percentages (For accompanying fauna see Table VI)

Sample
no.
26
49
24
54
65
19
23


51
7
30
12
56
55
31
52
60
53
61
I
59
2
57
58

Soil type II. IOO R.N. $=4.0$ to 3.9

\begin{tabular}{|c|c|c|c|c|c|}
\hline $\begin{array}{l}\text { "Organic } \\
\text { content" }\end{array}$ & $\begin{array}{c}\text { Medium sand } \\
0.5 \text { to } \\
0.2 \mathrm{~mm} \text {. }\end{array}$ & $\begin{array}{l}\text { Fine sand } \\
0.2 \text { to } \\
0.04 \mathrm{~mm} \text {. }\end{array}$ & $\begin{array}{c}\text { Silt } \\
\text { O.04 to } \\
0.01 \mathrm{~mm} \text {. }\end{array}$ & $\begin{array}{l}\text { Fine silt } \\
0.01 \text { to } \\
0.002 \mathrm{~mm} \text {. }\end{array}$ & $\begin{array}{c}\text { Clay } \\
<0.002 \mathrm{~mm}\end{array}$ \\
\hline- & $17 \cdot 7$ & $8 I \cdot 7$ & 0.0 & 0.5 & $O \cdot I$ \\
\hline$I \cdot I$ & $6 \mathrm{I} \cdot 4$ & $36 \cdot 4$ & 0.4 & $0 . I$ & 0.4 \\
\hline - & $39 \cdot 3$ & 59.8 & 0.2 & $0 . I$ & 0.7 \\
\hline$I \cdot 6$ & 55.5 & $4 I \cdot 3$ & 0.8 & 0.4 & 0.3 \\
\hline $3 \cdot 8$ & $39 \cdot 3$ & 54.8 & 0.9 & I. 0 & $0 \cdot I$ \\
\hline - & 18.0 & 79.5 & $1 \cdot 5$ & $I \cdot O$ & 0.0 \\
\hline - & $4 \cdot I$ & $92 \cdot 6$ & I. 7 & I. 4 & $I \cdot 2$ \\
\hline
\end{tabular}

Soil type I. IOO R.N. $=3 \cdot 8$ to $2 \cdot 0$

\begin{tabular}{|c|c|c|c|}
\hline 3.8 & II 0 & $79 \cdot 4$ & 4.7 \\
\hline & $3 \cdot I$ & $90 \cdot 3$ & I. \\
\hline & $7 \cdot 7$ & 82.9 & 4 \\
\hline & $7 \cdot 3$ & $82 \cdot I$ & 5 \\
\hline & $58 \cdot 7$ & $28 \cdot 7$ & 4 \\
\hline I & $40 \cdot 2$ & $45 \cdot 4$ & \\
\hline- & 19.9 & 65.8 & \\
\hline 5 & 3.9 & $72 \cdot 0$ & \\
\hline 3 & 33.7 & $42 \cdot I$ & \\
\hline 2 & $28 \cdot 5$ & $46 \cdot 5$ & 10 \\
\hline & 13.5 & 57.7 & IO \\
\hline & 25.4 & 46.8 & II \\
\hline & 12.5 & 53.4 & I2 \\
\hline & 10.8 & 56.9 & \\
\hline & $24 \cdot 3$ & $34 \cdot \mathrm{I}$ & I4 \\
\hline & 0.5 & $26 \cdot 2$ & \\
\hline
\end{tabular}

\begin{tabular}{|c|c|}
\hline$I \cdot O$ & $I \cdot O$ \\
\hline 2.9 & $2 \cdot I$ \\
\hline $3 \cdot 4$ & I. 4 \\
\hline 4.5 & 0.9 \\
\hline 4.5 & I. 8 \\
\hline $6 \cdot 4$ & I. 6 \\
\hline $\begin{array}{l}5.5 \\
7.5\end{array}$ & $1 \cdot 3$ \\
\hline & I. 8 \\
\hline $\begin{array}{l}8.4 \\
8.4\end{array}$ & 3.2 \\
\hline $8 \cdot 4$ & $2 \cdot 3$ \\
\hline $9 \cdot 4$ & $3 \cdot 4$ \\
\hline II $\cdot 3$ & $5 \cdot 6$ \\
\hline I3.I & 3.7 \\
\hline II 0 & $3 \cdot 2$ \\
\hline I4.7 & $7 \cdot 1$ \\
\hline $30 \cdot 3$ & 6.8 \\
\hline
\end{tabular}


A statement of the moisture content has been given in some samples, as being of obvious importance in an intertidal area. The samples in which this is not noted had been oven-dried after collection, prior to analysis by Borley's method. The organic content of the soil has not, to my knowledge, received much attention from oceanographers, yet this must also be of importance to the infauna as a whole, and that not only in quantity, but also very probably in quality. Thus, presumably, an animal provided with jaws will tend to use them in comminition of coarse, recognizably organic matter which, to a current feeder, such as Cardium edule, or a "mud browser", such as Arenicola, would probably be of little or no value. Beside the physical state of the debris the chemical composition will also be important, but as it is not known exactly what chemical elements, and in what amount and combination, the various animals require, attention has been directed only to the first, i.e. to an estimate of the total organic matter present, and a separation of that recently deposited and still recognizable as such, from that now intimately connected with the soil particles themselves. This separation was most conveniently effected by means of the $0.2 \mathrm{~mm}$. sieve.

In the fourteen samples investigated the amount of coarse organic matter is everywhere low, being highest at the base of the dyke (sample 50), and the percentage organic content does not appear to follow the R.N. very closely. Table V has been compiled by collecting together soil with the same percentage of recognizable, coarse, organic matter; and averaging for each grade so obtained the fine organic matter, total organic matter, summation percentage of silts and clay, and R.N. $\times$ IOO.

\begin{tabular}{|c|c|c|c|c|c|}
\hline \multicolumn{6}{|c|}{$\mathrm{F}$ V } \\
\hline $\begin{array}{c}\text { Percentage } \\
\text { coarse } \\
\text { organic } \\
\text { matter }\end{array}$ & Samples & $\begin{array}{c}\text { Average } \\
\text { percentage } \\
\text { fine } \\
\text { organic } \\
\text { matter }\end{array}$ & $\begin{array}{c}\text { Average } \\
\text { percentage } \\
\text { total } \\
\text { organic } \\
\text { matter }\end{array}$ & $\begin{array}{l}\text { Average } \\
\text { summation } \\
\text { percentage } \\
\text { silt and clay }\end{array}$ & $\begin{array}{c}\text { Average } \\
\text { R.N. } \times \text { IOO }\end{array}$ \\
\hline $2 \cdot 6$ & 50 & 4.9 & $7 \cdot 5$ & $20 \cdot 4$ & 2.9 \\
\hline 0.3 & $54,55,60,56,49$ & I. 86 & & $9 \cdot \mathrm{I}$ & $3 \cdot 7$ \\
\hline 0.2 & $5 \mathrm{I}, 52,53,57,6 \mathrm{I}, 65$ & $4 \cdot 4$ & $4 \cdot 43$ & 17.9 & $3 \cdot 4$ \\
\hline $0 . \mathrm{I}$ & 58,59 & $5: 9$ & $6 \cdot 0$ & $47^{\circ} \circ$ & $2 \cdot 4$ \\
\hline
\end{tabular}

Considered on this average basis, the R.N. and summation percentage of silts and clay show a relation with the fine organic content, and a slighter one with the total organic content, owing to the addition in sample 50 of a relatively large amount of coarse organic matter which was not deposited with the soil. The above figures, excluding sample 50, also indicate that the amount of coarse organic matter falls as the fine rises, so that the presence of the two divisions appears to be not entirely due to identical factors. Further, there is less coarse and more fine organic matter as the soil grows finer.

Table VI has been arranged without regard to topography, the samples being tabulated in ascending order of value of the summation percentage content of silts and clay, and it will be seen that the presence of the same 
Table VI. Soll Associations. Period of SAmpling: Early SEPTEMBER TO MID-FEBRUARY

Soil type II

Soil type I

Summation $\%$ of silts

$$
\text { and clay }
$$

IOO R.N.

Organic content

Moisture content \%

Number of sample

Association I:

Corophium volutator.

Nereis diversicolor

Oligocheta (pitted)

Oligochaeta (smooth)

Oligochaeta (smooth)

Nematoda

Leptidae larva

Paragnathia formica

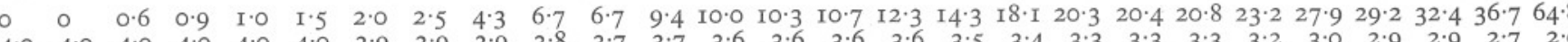

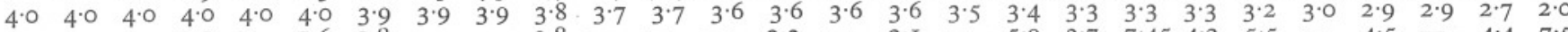

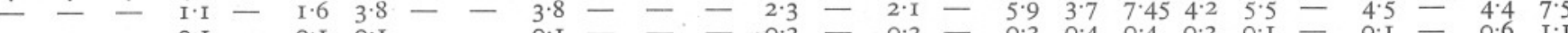
$\begin{array}{llllllllllllllllllllllllllll}63 & 64 & 26 & 49 & 24 & 54 & 65 & 19 & 23 & 51 & 7 & 30 & 62 & 56 & \text { I2 } & 55 & 31 & 52 & 60 & 50 & 53 & 61 & 1 & 59 & 2 & 57 & 58\end{array}$

Association II:

Macoma balthica

Cardium edule

Corophium arenarium

Pygospio elegans

Eulatia sp.

Scoloplos armiger

Scrobicularia plana

Retusa alba

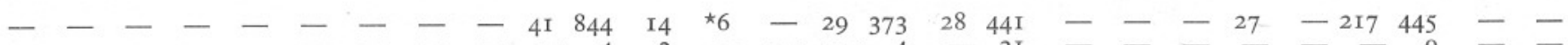

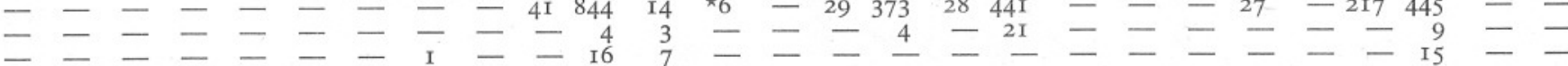

- $\overline{6}-\overline{\mathrm{I}}-\mathrm{-}-\mathrm{I}-\mathrm{I}-\mathrm{I} \mathrm{I}^{7}$

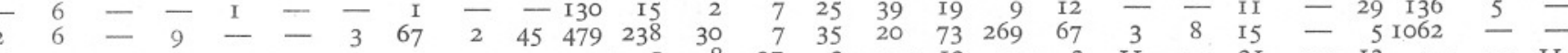

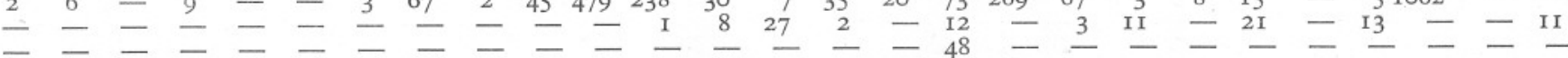

Bathyporeia pilosa

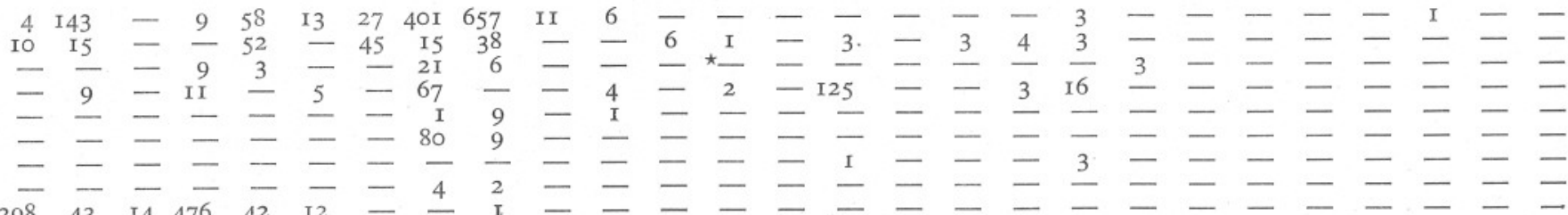

* Possibly a mixture of $C$. volutator and $C$. arenarium. 
groups of species is indicated, the Macoma community occurring in samples with a percentage lower than $6 \cdot 7$, and the Corophium community in the rest of the samples. Bathyporeia pilosa appears to be practically confined to soils with a summation percentage of $I$ or less.

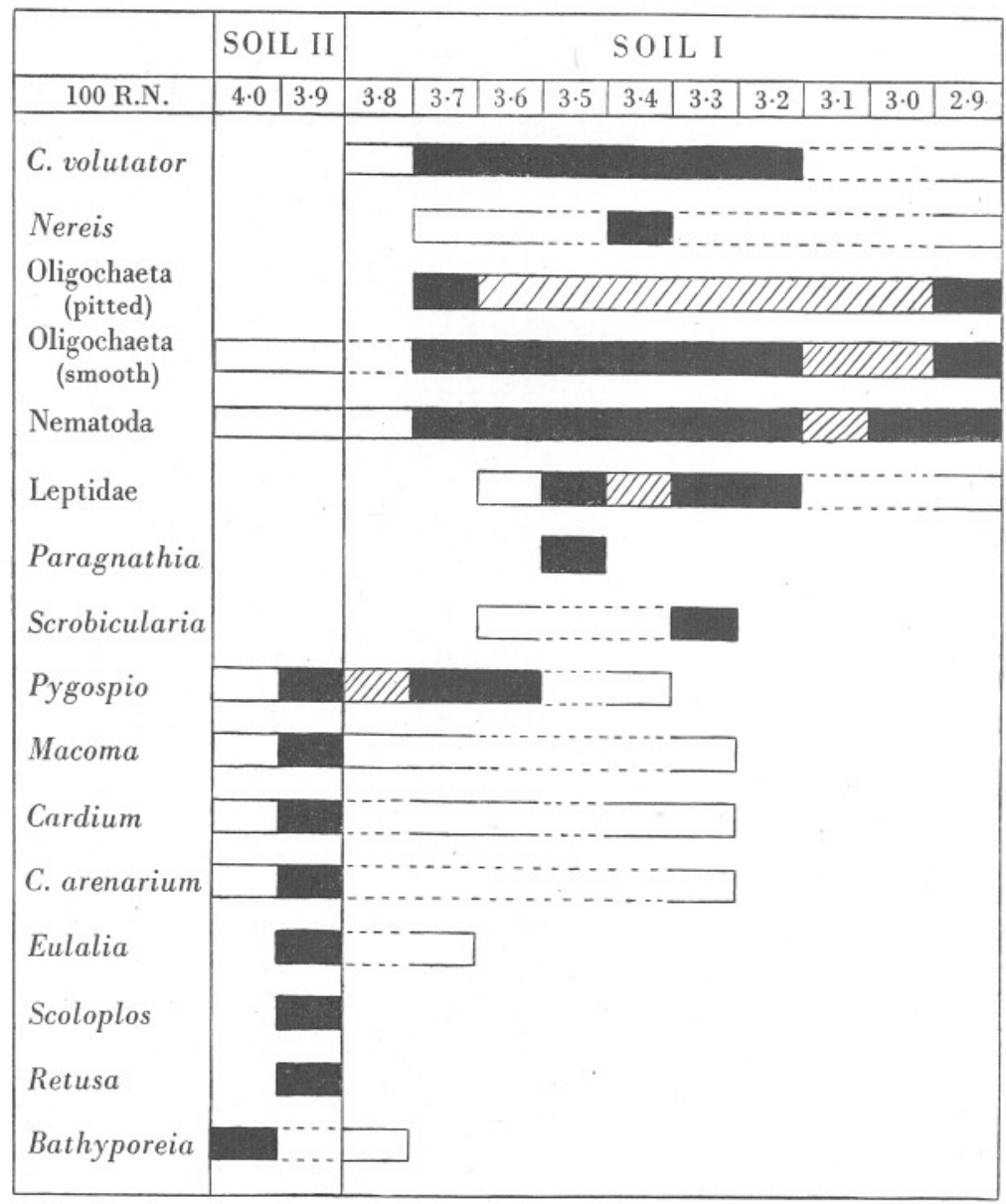

Fig. 3. Distribution of species according to soil grade. $50 \%$ zone, actual in black, assumed hatched; casual occurrences, actual outlined with continuous line, assumed outlined with broken line.

The smallness of the area sampled made it impossible to fix definite "class intervals" for the soil grades, but an attempt to trace a soil association in the area, following Davis, gave the following striking similarity with the "community" divisions (Table VII) in which the figures (number of individuals per sample per soil) are given correct to the first decimal place. Class A species have their " $50 \%$ zone" (Davis, 1925, p. I3) confined to one soil; class B in both, and class $\mathrm{C}$ includes casual occurrences. 


\section{TABLE VII}

\begin{tabular}{|c|c|}
\hline & $\begin{array}{l}\text { Soil type I (I } 6^{\star} \text { samples } \\
\text { IOO R.N. }=2.9 \text { to } 3.8\end{array}$ \\
\hline Class A & $\begin{array}{l}\text { Corophium volutator (I54) } \\
\text { Oligochaeta }(29 \cdot 5) \\
\text { Nematoda }(\mathrm{I} 47 \cdot 8) \\
\text { Nereis diversicolor }(2 \cdot 6) \\
\text { Leptid larvae }(6 \cdot \mathrm{I}) \\
\text { Paragnathia }(3 \cdot 0)\end{array}$ \\
\hline
\end{tabular}

Class B Pygospio elegans (8.7)

Class C Macoma balthica (I·3)

Cardium edule $(\mathrm{I} \cdot \mathrm{3})$

Corophium arenarium $(0.2)$
Soil type II (9 samples) IOO R.N. $=3.9$ to 4.0

Macoma balthica (I46.0)

Cardium edule (19.4)

Bathyporeia pilosa (98.4)

Corophium arenarium $(4 \cdot 8)$

Eulatia sp. ( $\mathrm{I} \cdot \mathrm{O})$

Scoloplos armiger (9.9)

Retusa alba (0.7)

Pygospio elegans (IO.I)

Oligochaeta $(\mathrm{I} \cdot \mathrm{O})$

Nematoda (9.9)

* Samples 57 and 58 are omitted from the calculations since they were from a barren mud area.

This table clearly shows that the soil association is identical with the Petersen community division previously advanced. Pygospio elegans is the only species in class $\mathrm{B}$, and it will be remembered that the species was formerly relegated to the Macoma community by recognition of a size distinction which would not be obvious on consideration of numbers alone. The casual occurrences also agree with the former division.

The zoning of the species from the point of view of soil associations is shown in more detail in Fig. 3, which includes the full range of each species. Samples in which the $50 \%$ zone was actually found are shown in black, samples in which it is assumed are indicated by diagonal shading. Casual occurrences found are shown in white with a firm outline; and where these are merely assumed the outline is dotted.

\section{Discussion \\ Macoma balthica}

It will be useful here to review the position with regard to the Macoma community. Petersen (1918, p. I7) states: "One community, the Macoma community, seems to be altogether independent of the composition of the level bottom, living equally well on pure sand and on pure mud." Davis (I925, p. I6) appears to suggest that the Macoma community is the only one that may be considered as a soil association, that is, it is limited as regards soil range. The above results, as far as they go, may appear to confirm Davis' statement, but further consideration points to the truth of the opposite view. Davis' soil I is, as far as I can judge, roughly comparable to the coarse part of my soil II, and as M. balthica occurs in the North Sea in soil IV only, it is listed as a class A species. Correlation with estuarine data, however, would give this species a much wider range of soils and support Petersen's remark concerning the catholicity of the species.

Remembering Davis' conclusion (p. I4) that, on the whole, the number of 
individuals increases with increasing fineness of soil, it is interesting to note that, as compared with O.II individuals of $M$. balthica per sq. $\mathrm{m}$. in soil IV (Davis), I have an average of I46 individuals per sq. ft. (=about I550 per sq. m.), while Fraser (1932, p. 82) found 3071 per sq. m. in "thick mud" (apparently finer than mine) and as many as I030 per sq. $\mathrm{m}$. in the muddy sand of his Corophium area. Thus Fraser finds Macoma in great abundance in two neighbouring soils of different texture (but with abundant microflora), in this case with the sand lying landward of the mud. That soil grade in itself is not a determining factor is further suggested by comparing the results of Bassindale (1938) and Rees (1940). The former finds it intolerant of both soft and clayey muds in the Mersey estuary, the latter finds it common in both on the Bristol channel. Thus the "50\% Zone" of Macoma is not an absolute reality, but differs with the locality. The abundance of Macoma in estuaries possibly depends on two factors: (a) quality and quantity of available food supply, correlated with type of soil; and $(b)$ available feeding time, correlated with distance below high-tide mark.

\section{Corophium volutator}

Hart (1930, p. 768) concludes that the distribution of $C$. volutator is limited by the type of soil, the most suitable being fairly soft grey mud. This description applies to the Corophium ground in the Dovey estuary, but I cannot with any confidence identify any of his soil analyses with any of mine. Nicol (I935, p. 220) thinks the importance of the soil second to that of salinity, finding Corophium as only a temporary inhabitant of the Aberlady salt marsh pools with a salinity of $5 \%$ or less, but that in the salter pools it is dependent on the type of bottom. I find it can live about six days in a salinity of $3 \%$, but cannot agree with Hart as to its length of survival in fresh water. While agreeing that Corophium is found in most abundance within a certain fairly recognizable type of soil, and that it has a wide range of salinity toleration (though with a definite lower limit), I am inclined to think that the distribution of this form is dependent rather on the primary factors determining the soil and salinity than on these secondary factors themselves, i.e. on slow current, and the meeting in the immediate neighbourhood of fresh and salt water.

In studying the ecology of $C$. volutator it may be most important to distinguish between areas where it is found over a period of months only and such a one as the Dovey estuary where it has been known over a period of thirteen years. Quatrefages (quoted in Bate \& Westwood, I863, p. 495) states: "about the end of April they come from the sea in myriads... and disappear in a single night about the end of October, to return again the following year." Ehrenbaum had a similar idea: "Uebrigens sind auch diese Corophien keine permanenten Bewohner der hochgelegenen Wattflaechen, sondern sie erscheinen dort zu Beginn der warmen Jahreszeit und verschwinden im Herbst wieder." Thus both Quatrefages and Ehrenbaum knew Corophium 
as a summer visitor, though when present the latter recorded as many as 50,000 per sq. m. Unless these writers are proved mistaken, this aspect of Corophium volutator must be included in any complete account of, and explanation of, its ecology. No indication of this possibility is found in this part of the Dovey estuary, and comparison of various localities from which $C$. volutator has been recorded suggests a possible reason for this difference in permanence.

In the summer of I900 Allen \& Todd recorded the species as very abundant in the Salcombe estuary, between Ditchend and Southpool Lake, in the typical type of mud. I examined this spot in March 1927, and after careful search found only two individuals. In April I929, Hart (I930, p. 776) found a population in this part of less than one per sq. $\mathrm{m}$. In the summer of the following year, I90I, Allen \& Todd found it abundant in one part of the Exmouth estuary, near high tide and north of Salt House Lake, together with many species recorded in this investigation. I visited this spot in March I927 and this time found neither Corophium nor Corophium mud. The mouths of the rivers Exe and Dovey are very strikingly similar, the one being the "mirror image" of the other, reading Exmouth for Aberdovey, Dawlish Warren for Borth Dunes, and Salt House Lake for the River Leri, with Corophium grounds in equivalent spots of each. I learnt that cartage of sand had recently resulted in the sea breaking through the Warren at Dawlish, with an obvious decrease in the shelter provided. This suggested the idea that in some way Borth Dunes might be a factor in the persistence of Corophium in the estuary of the Dovey. The only two places where I found abundant Corophium at Plymouth in I927 were behind sluice gates in Landulph marsh, but not on the banks of the Tamar outside; and similarly behind sluice gates in Chelson meadows, though absent from the neighbouring banks of the Plym. Hart (p. 768) records large numbers also behind a sluice gate connecting a small river with "Stukey Freshes", a tidal creek in Norfolk. In the first two localities Corophium was present without its typical soil, but with very adequate shelter from any current until the sluice gate should be open. Thus, although the typical soil was absent, it was in still water that would have deposited any clay precipitated by a mixing of fresh and salt water, and thus favour production of such a soil.

Other records have been examined with a view to determining whether the Corophium ground was especially sheltered in any way, choosing those in which the population was fairly dense. Most of Hart's figures record relatively small populations and may possibly be found to be transitory occurrences; however, in August I929 he found I000 per sq. m. in a creek in a Salicornetum at Blakeney Point, Norfolk (p. 768), where presumably the current is slow. Fraser (I932, p. 70) found it abundantly on Dingle Beach, River Mersey, near the mouth of a small sewer, adequately protected by a revetment. Bassindale (I938, p. 85) found it higher up the River Mersey than Fraser, and on the opposite bank, in mud and muddy sand watered by two 
freshwater streams, namely Holpool Gutter and the River Gowy and its tributary, where the supernatant current is very slow. In the outer Mersey Area Bassindale (p. 87) records it in an area sheltered by the East Hoyle Bank and their reef of rocks, with Macoma balthica and Arenicola marina replacing Corophium some distance away from the shelter of the reef, as in the Dovey estuary. Bassindale's records refer to the period between May and October I933. Percival (I929, p. 93) records it on the banks of the Tamar, where the slowness of the current is specially noted. Nicol (I935, p. 2I4-I8) records it as abundant in certain salt marsh pools in Aberlady Bay and also on the shores of the Peffer Burn in the neighbourhood of some hulks which possibly offer a degree of shelter and where a freshwater stream is shown running across the mud. Elmhirst (1932, p. 59) records a population of 2000-10,000 per sq. m., together with 24,000-32,000 nematodes and 20,000-48,000 oligochaetes in samples to a depth of I $5 \mathrm{~cm}$. on Fairlie sands, coast of Ayrshire; I do not know what degree of shelter there was in this area. Rees (I940, p. I9I) records it in large numbers (2400 per m. $\left.{ }^{2}\right)$ beside a sewage outfall at low-water mark near Cardiff, but thinks it is probably transitory.

It seems, then, that in many places where Corophium has been noted in abundance there is a special factor for shelter in the neighbourhood, and often a freshwater stream. From these considerations, together with some experimental work not yet published, I am led to suggest the following explanation of the occurrence, both transitory and permanent, of Corophium volutator. I have a certain amount of reason to believe that under certain combinations of light and salinity $C$. volutator may leave the soil and "swim" until stranded by the falling tide. Where the water movements are very gentle, such as near a high-tide line in a sheltered area, it will be redeposited not very far from its original position and, if still over the appropriate proportions of silt and clay, will burrow. A clayey soil of IOO R.N. $=2$ will be too stiff to allow easy penetrability, and a more sandy one of IOO R.N. $=4$ will be associated with too strong a supernatant current to deposit Corophium. Any individuals which succeed in burrowing, in spite of the current, will lack the safeguard from desiccation provided by the normal clay burrow. On the other hand, if the community emerges from the soil into a stronger current, in a region without suitable shelter, it may well " disappear in a single night", being carried out to sea.

I make this as yet unproven suggestion as one means of testing its truth. It would be interesting if further records of Corophium volutator could include (a) the length of time it has persisted in the area, $(b)$ any factor for shelter, (c) the presence or absence of freshwater streams over or near the bed, decreasing the salinity but also favouring the deposition of the necessary clay for burrowing, $(d)$ evidence of sewage pollution, which is possibly a nutritive factor. 


\section{REFERENCES}

AlleN, E. J., I899. On the fauna and bottom deposits near the 30 -fathom line from the Eddystone Grounds to Start Point. Fourn. Mar. Biol. Assoc., Vol. v, pp. 365-542.

Allen, E. J. \& Todd, R. A., Igoo. Fauna of the Salcombe estuary. Fourn. Mar. Biol. Assoc., Vol. vi, p. I5I.

- I90r. The fauna of the Exe estuary. Fourn. Mar. Biol. Assoc., Vol. vi, p. 295.

Bassindale, R., I938. The infauna of the Mersey estuary. Fourn. Mar. Biol. Assoc., Vol. xxiII, pp. 83-98.

Bate, C. S. \& Westwood, P. O., I863. A History of the British Sessile-Eyed Crustacea, Vol. I, pp. 493-6. London.

Borley, J. O., I923. The marine deposits of the southern North Sea. Min. Agr. Fish, Fishery Invest., Series II, Vol. IV, No. 6, pp. I-62.

CRAWFord, G. I., I937. A review of the amphipod genus Corophium, with notes on the British species. Fourn. Mar. Biol. Assoc., Vol. xxi, No. 2, pp. 589-630.

Davis, F. M., I925. Quantitative studies on the fauna of the sea bottom. No. 2. Results of the investigations into the southern North Sea, I92 I-24. Min. Agr. Fish., Fishery Invest., Series II, Vol. viII, No. 4, pp. I-50.

DuRLACHER, F. W., I9I4. On the drift of sewage in the Dovey estuary in relation to the mussel beds. Trans. Biol. Soc. Liverpool, Vol. xxviII, pp. 335-52.

Elmhirst, R., I932. Quantitative studies between tide marks. The Glasgow Naturalist, Vol. x, pp. 56-62.

FRASER, J. H., I932. Observations on the fauna and constituents of an estuarine mud in a polluted area. Fourn. Mar. Biol. Assoc., Vol. xvirI, pp. 69-85.

Hart, T. J., I930. Preliminary notes on the bionomics of the amphipod Corophium volutator Pallas. Fourn. Mar. Biol. Assoc., Vol. xvi, pp. 76I-89.

Marine Biological Association, I93i. Plymouth Marine Fauna. 2nd edition.

Nicol, E. A. T., I935. The ecology of a salt marsh. Fourn. Mar. Biol. Assoc., Vol. xx, pp. 203-6I.

Percival, E., I929. Report on the fauna of the estuaries of the River Tamar and the River Lynher. Fourn. Mar. Biol. Assoc., Vol. xvI, pp. 8I-Io8.

Petersen, C. G. J., I9I8. The sea bottom and its production of fish foods; a survey of the work done in connexion with valuation of the Danish waters from I883 to I9I7. Rept. Dan. Biol. Sta., Vol. xxv, pp. I-62. Copenhagen.

Pirrie, M. E., Bruce, J. R. \& Moore, H. B., I932. A quantitative study of the fauna of the sandy beach at Port Erin. Fourn. Mar. Biol. Assoc., Vol. xviII, pp. 279-96.

ReEs, C. B., I940. A preliminary study of the ecology of a mud flat. Fourn. Mar. Biol. Assoc., Vol. xxiv, pp. I85-99.

RobINson, G. W., I922. A new method for the mechanical analysis of soils and other dispersions. Fourn. Agr. Sci., Vol. xII, pp. 306-2I.

Spooner, G. M. \& Moore, H. B., I940. The ecology of the Tamar estuary. VI. An account of the macrofauna of the intertidal muds. Fourn. Mar. Biol. Assoc., Vol. xxIv, pp. 283-330.

Stephen, A. C., I929. Studies on the Scottish marine fauna. Trans. Roy. Soc. Edin., Vol. 56, pp. 291-306. 